\title{
Mangrove Dynamics near Douala International Airport (Cameroon Coastal)
}

\author{
Fulbert Rodrigue Zogning Lontsi, Paul Tchawa, Joseph Youta Happy \\ Department of Geography, University of Yaounde 1, Yaounde, Cameroon \\ Email: fulbertrodrigue@gmail.com
}

How to cite this paper: Zogning Lontsi, F.R., Tchawa, P. and Happy, J.Y. (2021) Mangrove Dynamics near Douala International Airport (Cameroon Coastal). Open Access Library Journal, 8: e8184

https://doi.org/10.4236/oalib.1108184

Received: November 12, 2021

Accepted: December 18, 2021

Published: December 21, 2021

Copyright $\odot 2021$ by author(s) and Open Access Library Inc.

This work is licensed under the Creative Commons Attribution International License (CC BY 4.0).

http://creativecommons.org/licenses/by/4.0/ (c) (i) Open Access

\begin{abstract}
The purpose of this research is to assess the evolution of the mangrove swamp near Douala international airport over the past five decades. The study is based on the collection and processing of data (bibliographic, aerial photographs respectively from 1974, 2003 and 2009; Landsat Multispectral scanner satellite images from 1974, Quickbird from 2003 and Geo Eye from 2012 and 2020). The study is also based on observations and surveys (with 37 semi-interviews, 03 focus groups and the administration of a questionnaire to 217 households spread over the three districts of the perimeter). The analysis shows a regressive dynamic of the mangrove in favor of constructions, since the cover increases from (467.11), (357.53) and (212.53) hectares respectively in 1974, 2003 and 2012. The illustration of 2020 shows a considerable degradation of the remaining cover which is partly replaced by constructions. Several factors explain this degradation of the mangrove. These include demographic growth, ambient poverty, and the lack of specific legislation for sustainable mangrove management. The diversification of income-generating activities, the implementation of improved smokehouses and reforestation, and sensitization of the local population constitute solutions that can promote sustainable mangrove management.
\end{abstract}

\section{Subject Areas}

Ecology, Plant Science

\section{Keywords}

Dynamic, Mangrove, Douala, Sustainable Management

\section{Introduction}

In most African countries where mangroves are growing, recent studies show a 
gradual degradation of the vegetation cover. If the mangrove has long been defined as a muddy ecosystem devoid of any interest (Cormier SALEM, 1994) [1], the diversity of scientific research (Tomlinson, 1986 [2]; Nagelkerken, 2008 [3]; Spalding et al., 2010 [4]; Tusinski, 2012 [5]; Taillardat, 2013 [6] ...) and the projects (ISME-ITTO, 2009 [7]; FAO, 2018 [8] etc.) demonstrate this change in perceptions. Since the end of 19 century, several studies demonstrate proven utility of the mangrove swamp under constantly renewed human pressure. Most of these studies have relied on remote sensing to illustrate trends in the evolution of mangrove formations, particularly in Southeast Asia (Kuenzer et al., 2011 [9]; Son et al., 2015 [10]; Kanniah et al., 2015 [11]; pimple et al., 2018 [12]). The observation is the same in Africa (Bassene A et al., 2013 [13]; Zogning Lontsi, 2015 [14]; Boubakar S et al., 2018 [15]; Orekan V et al., 2019 [16]; Zogning Lontsi, 2021 [17]).

In Cameroon, recent studies illustrate a regressive evolution of the mangrove cover as a whole (FAO, 2005 [18]; MINEPDED-RCM, 2016 [19]; MINEPDEDRCM, 2017 [20]). This mangrove area would have declined from 250,000 in 2005 (FAO, 2005) [18], to less than 221,162 hectares in 2016 (MINEPDED-RCM, 2016) [19]. However, the areas and exploitation of the mangrove vary considerably depending on the site. The mangrove of the estuary of Cameroon estimated at around 103,817 ha (MINEPDED-RCM, 2016) [19] corresponds to the second largest extent of cover, according to the statistical illustrations presented in the Atlas of the Mangroves of Cameroon. In addition, this area constitutes a highly coveted area, due to its location near large cities such as Douala and Tiko where population growth is leading to occupation of the peripheral space generally occupied by mangroves (Yemmafouo et al., 2017) [21].

The research carried out on the evolution of the mangrove in the Wouri estuary does not always focus on the temporal evolution of specific mangrove plots, yet this approach should make it possible not only to inventory mangrove sites under strong pressure, but also to carry out a demographic and socio-economic analysis adapted to the environment. This zonal delimitation process already initiated by the Ministry of the Environment and Nature Protection (MINEP, 2010) [22] would also make it possible to take management measures according to the mangrove areas delimited around the city.

The main objective of this study is to analyze the spatial dynamics of the mangroves near the international airport of Douala, a coastal city in Cameroon. To achieve this, it is essential to first illustrate the dynamics of the canopy over the past 5 decades (between 1970 and 2020), before focusing on the factors and corrective solutions for sustainable management of the vegetation cover.

\section{Study Area and Methodology}

\subsection{Study Area}

The mangrove swamp near Douala International Airport, which is the subject of this study, is located at the south of the second city of Douala, precisely between 
latitudes $4^{\circ} 01-3^{\circ} 59 \mathrm{~N}$ and longitudes $9^{\circ} 42-9^{\circ} 43 \mathrm{E}$. This surface is limited to the north by the Douala International Airport, to the south by Doctor TOKOTO's Cove and the Takélé mangrove, to the east by a tributary of the NGOUA River and to the west of the district Youpwê by an expanse of mangrove. Figure 1 shows this location of the mangrove, which occupies a total area of approximately 467.11 hectares. Significant rainfall and temperatures, the annual averages of which are respectively between $4125 \mathrm{~mm}$ and $26.4^{\circ} \mathrm{C}$, characterize this area, partially made up of hydromorphic soils under the influence of diurnal tides.

\subsection{Methodology}

\subsubsection{The Data Collection}

To justify the knowledge acquired through the bibliographic data, this research

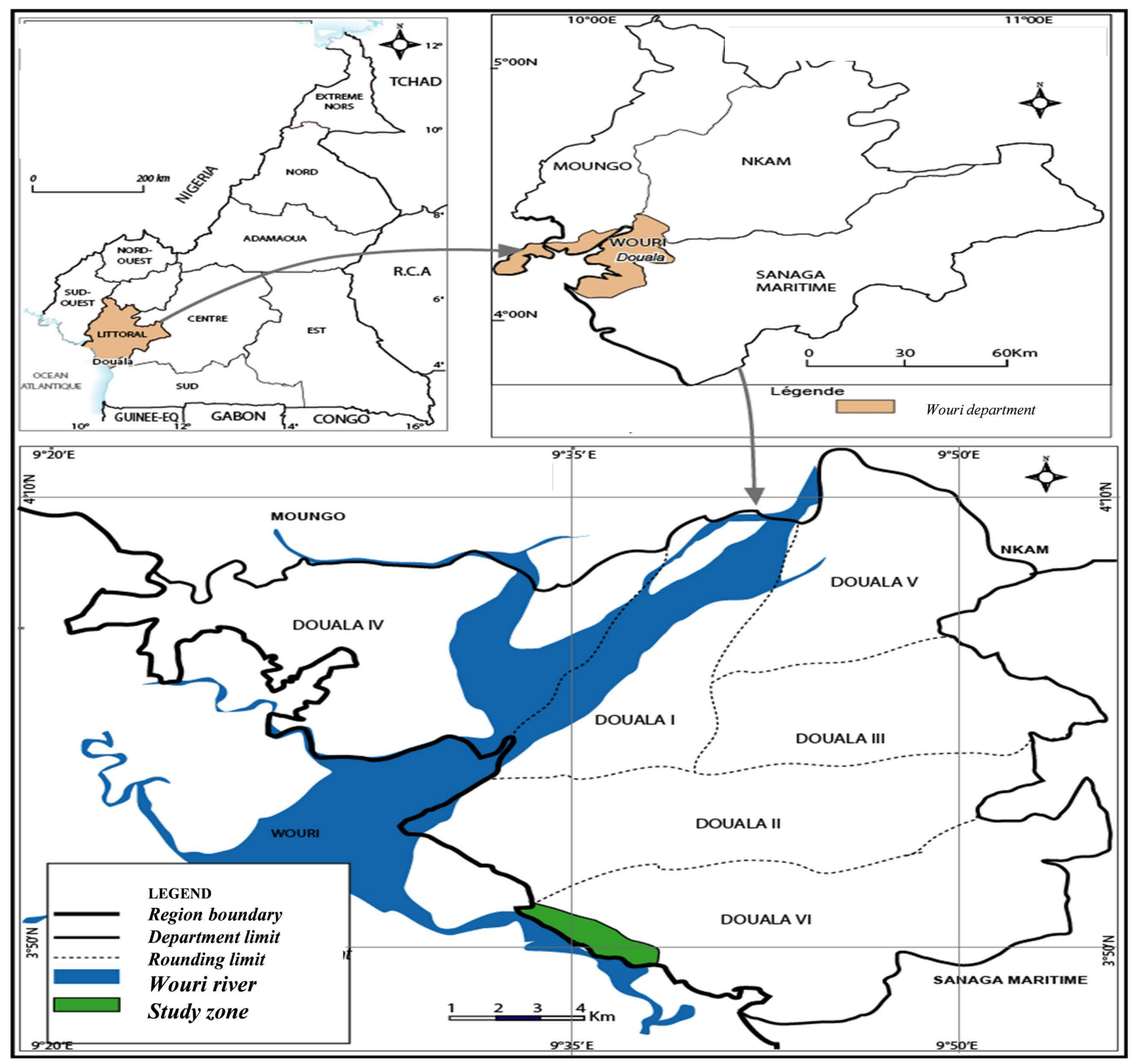

Figure 1. Location map of the study area. Source: Zogning Lontsi (2015) [23]. 
required the collection of aerial photographs respectively from the years 1974, 2003 and 2009. The downloading of the satellite images Landsat Multispectral scanner (year 1974), quickbird (year 2003) and Geo Eye (years 2012 and 2020) was also carried out to assess the recent evolution of the cover. The field trip was organized in several phases, namely semi-structured interviews (with 37 resource persons), field observations, focus groups (03 organized with the help of the three district heads) and the administration of a final questionnaire sent to 217 households spread over the different districts of the perimeter (92 in Youpwê, 56 in New-Priso and 69 in Bois des Singes). This survey was used to collect specific information (knowledge of the mangrove, perception of its evolution, management strategies and difficulties related to the exploitation of the mangrove).

\subsubsection{Data Analysis and Interpretation}

The data collected was analyzed separately. The processing of cartographic data required the use of specific software (Quantum GIS 1.8; Adobe Illustrator 11 and Envi 4.7). With regard to satellite images, the study involved the use of two types of processing, namely geometric processing (to make each pixel of the ortho-images correspond to the same elements in the field). Radiometric treatments were also carried out. They made it possible to mix the information of each image in a common image in order to preserve in this one, the best spectral information of each image. The operation consisted of the red-green-blue coding and in the analysis of the principal components. The analysis of the data obtained was carried out by the Normalized Difference Vegetation Index which is an index of vegetation highlighting the dynamism of the vegetation, by its chlorophyll content and the structure of plant cover. This index is obtained by the following equation:

$$
\mathrm{NDVI}=\frac{\mathrm{PIR}-\mathrm{R}}{\mathrm{PIR}+\mathrm{R}}
$$

with $\mathrm{R}$ corresponds to the visible band of red, and PIR to the visible band of the near infrared.

NDVI values are generally between -1 and +1 . Negative values correspond to surfaces for which the reflectance in the red is greater than that of the near infrared. This is generally the case for liquid environments (snow, water and clouds) that differ from bare soils, which often have values close to zero. With regard to plant cover, these are surfaces, which always present positive values, which are generally between 0.1 (less dense vegetation) and 0.7 (more dense vegetation).

The use of the NDVI index is linked to the fact that it is used not only to illustrate vegetation dynamics, but also to distinguish and classify land cover (Patakamuri et al., 2014) [23]. It was at the end of these treatments that the images were integrated into the synthesis maps. The same applies to the calculation of the areas of the different layers, as well as the preparation of land use maps for each period. Regarding the processing of responses to questionnaires adminis- 
tered to households, the use of SPSS 11 software made it possible to have the results in the form of figures and tables.

\section{Results}

A Spatiotemporal Dynamics of the Mangrove near the Douala International Airport between 1970 and 2020

Figure 2 shows the dynamics of land use during the periods 1974, 2003 and 2009. It shows a considerable degradation of the mangrove and an evolution of plantations and dwellings.

In Figure 2, which show a spatial evolution of the mangrove in three distinct time intervals, the 1974 landscape presents three main homogeneous themes

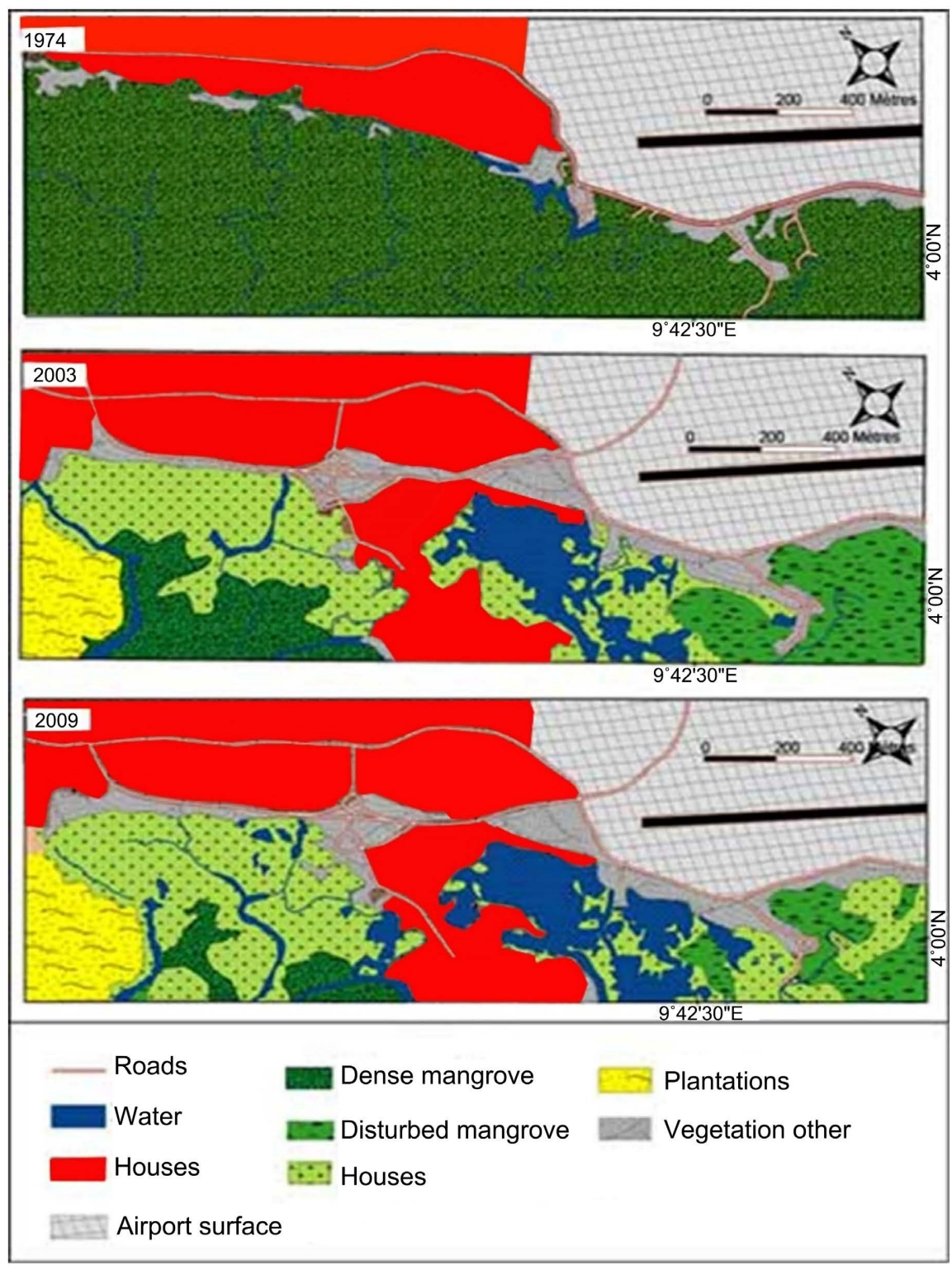

Figure 2. Dynamic of the mangrove near the airport between 1974, 2003 and 2009. Source: Aerial photographs 1974, 2003 and 2009. 
namely a dense mangrove, buildings and the surface of the airport. Looking at the changes over three decades, it is fundamental to note this growth in new themes and existing themes that are observed. These mutations are observed exclusively in the dense mangrove, which was partially colonized in 2003 by both dwellings, plantations, disturbed mangrove, severely degraded mangrove, water and other types of vegetation. The regressive dynamics of the cover are more evident in the light of the changes observed in the landscape in 2009. These are nevertheless the same themes, which occupy more surface area compared to the mangrove, which is regressing considerably. A very small part of dense mangrove remains, near the much-degraded mangrove, which is considerably represented, compared to the degraded mangrove. These illustrations are further highlighted in Figure 3, which also incorporate notable changes between 2001 and 2012.
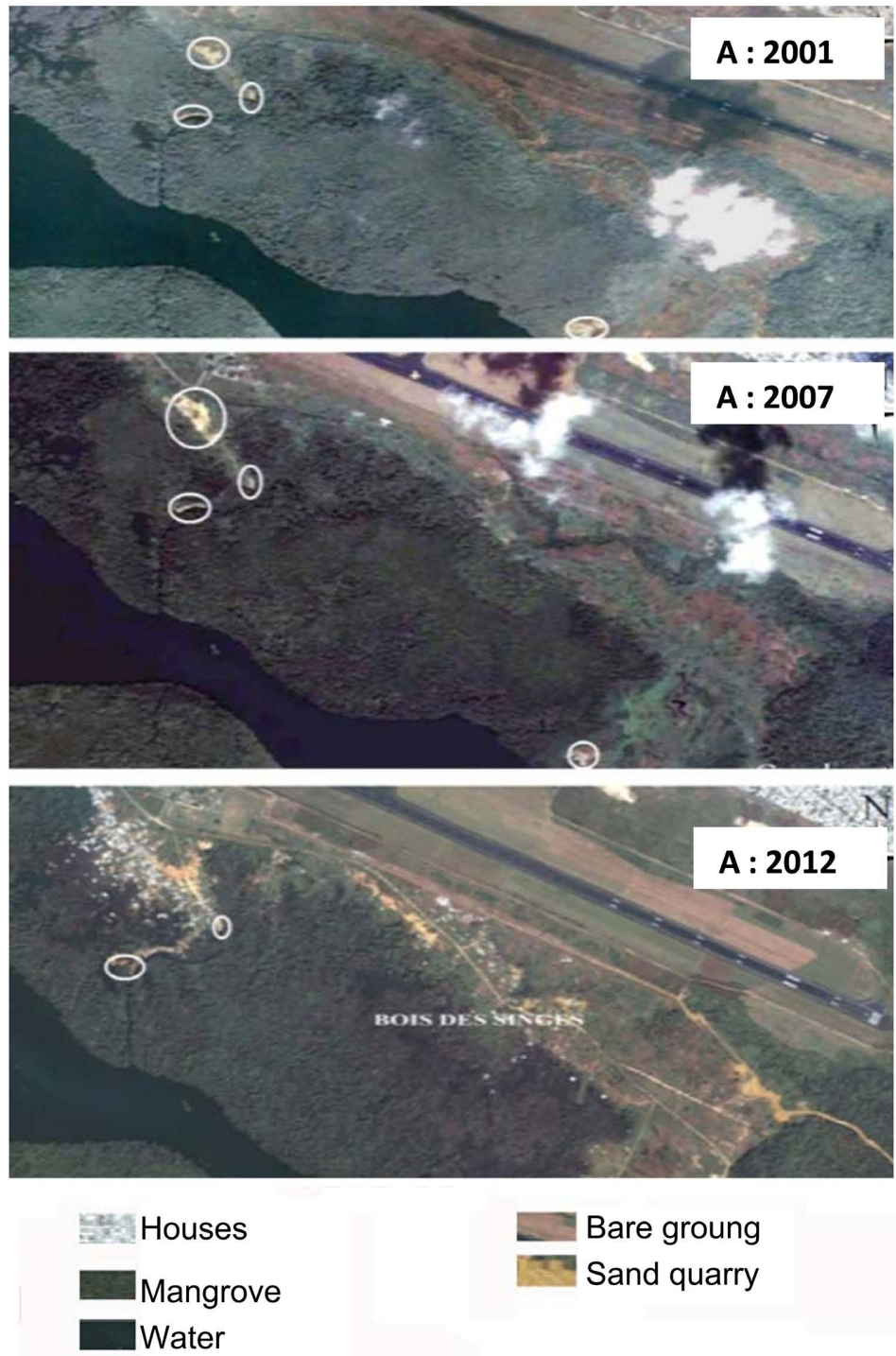

Figure 3. Evolution of mangrove landscapes in Bois des Singes between 2001 and 2012 (sand pits circled in white). Source: Google Earth satellite images (from 2001, 2007 and 2012 respectively). 
With regard to Figure 3, it presents the dynamics observed in the first decade of the year 2000, precisely at the level of the mangrove of the Bois des Singes, which, with regard to Figure 2 constitutes the most extensive surface concerning less disturbed mangrove. This site is experiencing disruption between 2007 and 2012, an interval which represents an appearance of grouped and scattered constructions, but also bare soils in a space partially dominated by mangrove in the period from 2001 to 2007. It is the same goes for sand quarries, the dynamics of which call into question the strategies of anthropization of mangrove surfaces. Figure 4 presents this dynamic of changes between 1974 and 2012.

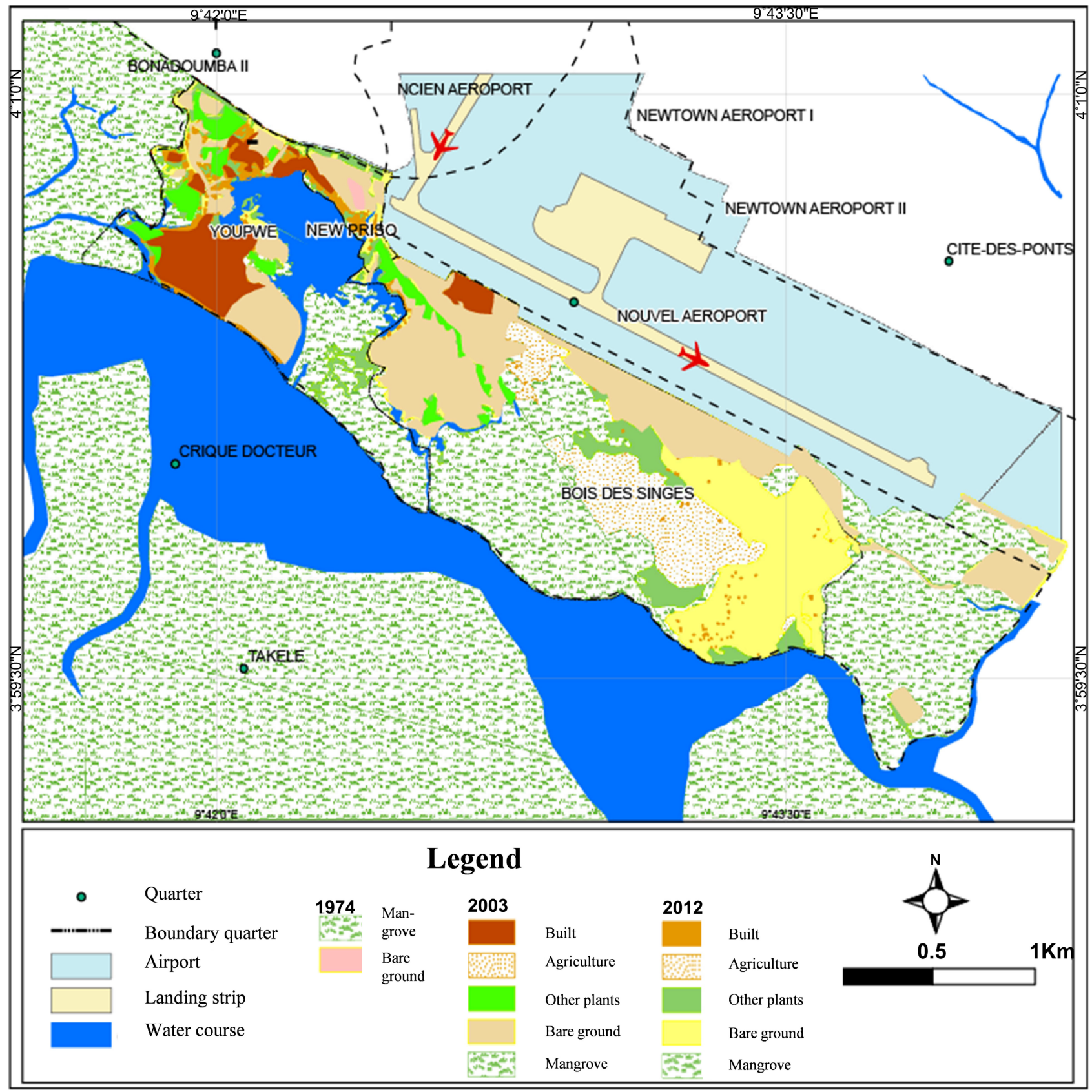

Figure 4. Spatiotemporal evolution of the study area between 1974 and 2012. Source: ZOGNING L (2014) [23]. 
Figure 4 shows an evolution of land use between 1974 and 2012. It illustrates considerable changes in an environment, which, according to the initial map (1974), consisted exclusively of three themes, namely mangrove, water and bare floors. About two decades later and in 2003, the illustration shows an appearance of new subjects to the detriment of mangroves. These include buildings (Youpwê and New-priso districts), agricultural plantations and other types of vegetation. At the same time, the mangrove of Bois des Singes presents change, with the appearance of agricultural plantations and buildings that can be observed at the south of airport. This dynamic of change is seen more in 2012 with the representations of buildings, bare soil and other types of vegetation that can be observed around the mangrove. The statistical summary of the changes is presented in Table 1.

Table 1 shows statistical changes observed in the landscapes of the previous figures. This illustration confirms the uniformity of the mangrove in 1974, when the dense cover constitutes an area of 467.11 hectares. As in Figure 3, the table shows notable changes in 2003, with the appearance of new themes, namely buildings (20.55 hectares), bare soils ( 58.10 hectares), agricultural plantations (10.91 hectares), sand quarries (1.20 hectares)... These elements justify the total loss observed, since the mangrove shrinks from 467.11 to 357.53 hectares. The figures presented in this table further justify the dynamics observed in Figure 4, since the mangrove swamps between 2003 and 2012, notably from 357.53 to 287.55 hectares. In the four decades extending from 1974 to 2014 , the table shows a loss of 179.55 hectares of mangrove, with significant regressive dynamics during the decade 2002-2012.

Three major observations can be found in this spatiotemporal evolution of the mangroves near Douala airport. The first is that of a regressive dynamic which gradually evolves from West to East, with regard to the dynamic observed in

Table 1. Statistical dynamics of the mangrove between 1974 and 2012.

\begin{tabular}{|c|c|c|c|c|c|c|}
\hline Type & Area 1974 & Frequency & Area 2003 & Frequency & Area 2012 & Frequency \\
\hline & (ha & (\%) & (ha) & (\%) & (ha) & (\%) \\
\hline Built & - & - & 20.55 & 4.40 & 39.76 & 8.51 \\
\hline Bare ground & - & - & 58.10 & 12.44 & 68.8 & 14.73 \\
\hline Agriculture & - & - & 10.91 & 2.34 & 39.98 & 8.56 \\
\hline Sand quarries & - & - & 1.20 & 0.26 & 4.20 & 0.90 \\
\hline Dense mangrove & 467.11 & 100 & 188.99 & 40.45 & 74.99 & 16.06 \\
\hline Degraded mangrove & - & - & 168.54 & 36.08 & 212.56 & 45.50 \\
\hline Other vegetation & - & - & 7.98 & 1.71 & 18.98 & 4.06 \\
\hline Water & - & - & 10.83 & 2.32 & 7.83 & 1.68 \\
\hline Total & 467.11 & 100 & 467.11 & 100 & 467.11 & 100 \\
\hline Total losses & & & 109.57 & & 179.55 & \\
\hline
\end{tabular}

Source: Data extracted from aerial photographs (1974 and 2003) and the 2012 Geo Eye satellite image. 
Figure 4. The second observation is based on the mutation of mangrove landscapes between the disturbed stages and human settlements. In fact, degraded mangrove cover is increasingly being replaced by housing, while virgin mangrove areas are evolving towards degraded stages. Moreover, the regressive dynamic was expressed greatly between 2003 and 2012 than it was during the three preceding decades. This disproportionate degradation since the second millennium can be seen more in relation to the dynamics of the canopy in 2020 (Figure 5).

The photo board on the previous page illustrates the current state of the mangrove swamp near the airport. It presents a considerable increase for building that replaces the virgin and degraded mangrove in 2012. These changes confirm this trend towards the conversion of mangroves near large cities. Indeed, the preponderance of constructions clearly allows man to be considered as the main actor in the degradation of the mangrove plant cover near the airport.

\section{Discussion}

\subsection{The Factors of Mangrove Anthropization}

\subsubsection{Population Growth and Occupation of Peripheral Space}

This study highlights population growth (Figure 5) as the main factor in the degradation of mangroves. A study by Mainet (1985) [24], shows that the urbanization of the city of Douala, which develops over more than $30 \mathrm{~km}$ (from West to East) and over approximately $10 \mathrm{~km}$ from north to south, is characterized by areas of spontaneous most often won on sometimes marshy land where working-class neighborhoods are established. The city of Douala has experienced increasing urbanization since the end of the Second World War. This extension is also linked to economic development through the development of macroeconomic infrastructure. The creation of the port and the airport notably increased this spatial extension towards the peri-urban mangrove swamp. The research results of Bassene et al. (2013) [13], Orekan et al. (2019) [16] follow the same logic.

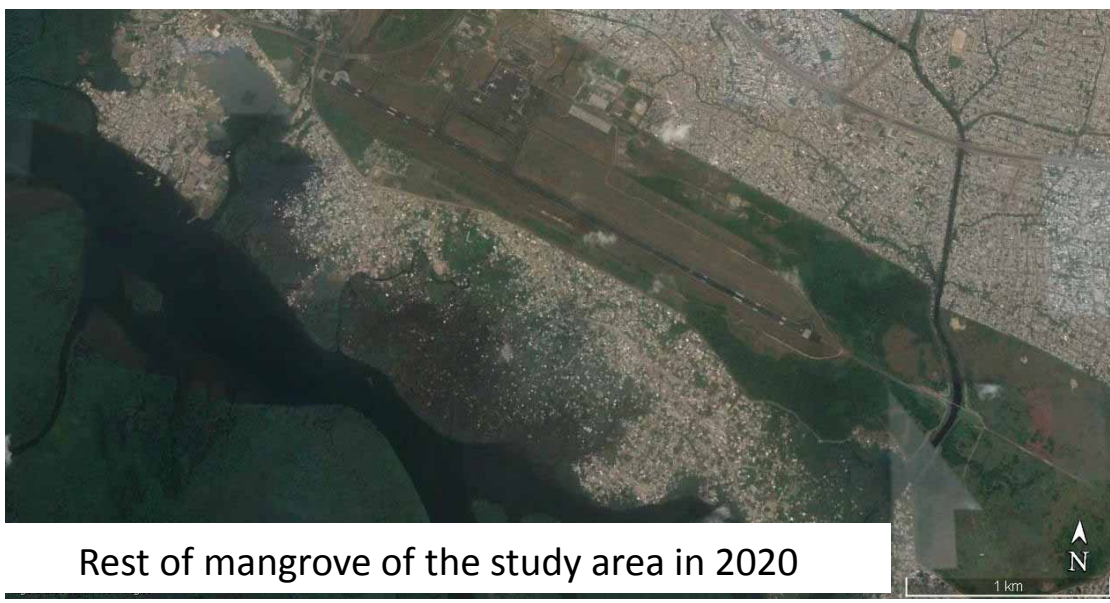

Figure 5. Occupation of the mangrove near the airport in 2020. 
The regressive mangrove dynamics is also linked to the excessive cutting of mangroves for socio-economic income (Din et al., 2008 [25]; Dzalla, 2014 [26]). While logging appears to be one of the main causes of mangrove degradation near Douala airport and in the towns of Ziguinchor and Tobor in Senegal, it should be noted, on the other hand, a negative influence of salt production activities on degradation of the mangrove swamp of Benin (southwest of Avloh, locality of Avlékéte). Contrary to the causes of the mangrove degradation observed in West and Central Africa, except for urban expansion and marine pollution which set up an analogy in most mangrove regions, the aquaculture industry constitutes one of the main causes of mangrove degradation in Southeast Asia in general and Indonesia in particular (WRM, 2013) [27].

Communities that settle in the mangrove environment also exploit the ecosystem for its economic success. It is in particular the place where fishery resources such as mangroves, fish and sand are taken. Plate 1 illustrates these main activities at the origin of the irrational exploitation of the mangrove.

Plate 1 presents the main activities carried out in the mangrove environment near the airport. These include construction, exploitation of mangroves and sand. Photo 1 and Photo 2 of the plate show destruction of the surrounding mangrove forest before the installation of the frame itself. The development of

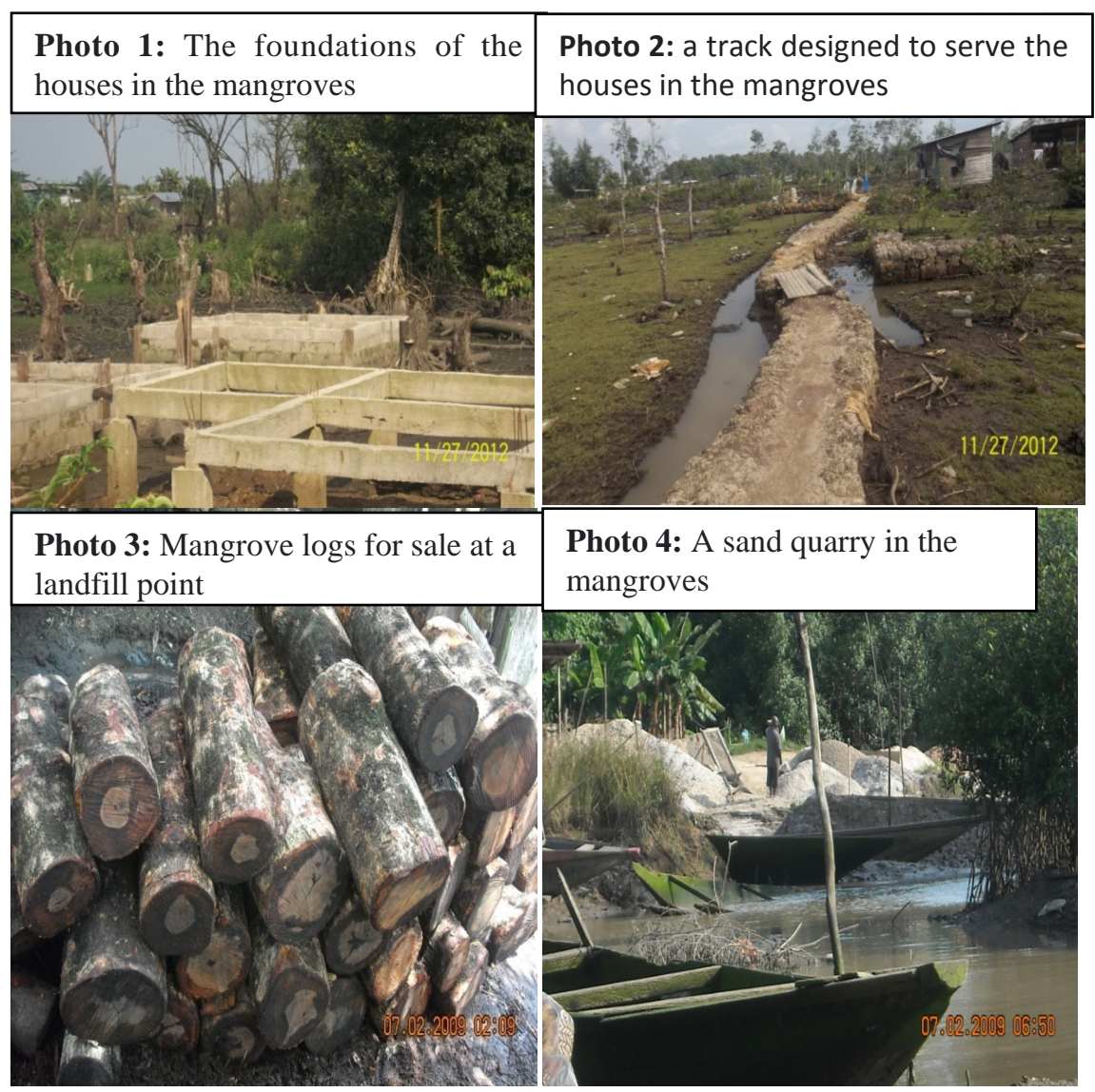

Plate 1. The main activities carried out by the population living in the mangroves near the airport. 
the site involves the use of silt and pozzolana for the backfill. As for the silt, which is essential for the development of mangroves, it is taken from the immediate environment and helps control surface and subsurface flooding. It is laid out in a "median" before the foundation is laid out, and makes it possible to create tracks in the mangrove environment (Photo 2) of the previous sheet.

Photo 3 and Photo 4 of Plate 1 also illustrate other causes of degradation of the canopy. Regarding the red mangroves, which constitute the main abundant and dominant species (Zogning Lontsi, 2015) [14], the logs (Photo 3) are sold to households and traders who use the gasoline as wood of heating. Regarding the exploitation of sand, which is a lucrative activity (for the neighboring populations of the mangrove), it is carried out in the subsoil of the mangrove, and facilitates the release of deposits in an already very little developed soil. It also facilitates the fall of mangroves and limits the spread of propagules.

\subsubsection{The Lack of Supervision by Public Authorities}

The conversion of mangrove cover into habitats is also linked to the lack of supervision from public authorities. In fact, Law No. 96/12 of August 5, 1996 (République du Cameroun, 1996) [28], which serves as a compass for the main guidelines for environmental management, does not present a logical and explicit framework for mangrove management. This is particularly the case with article 94 of the said law, which stipulates, "mangrove ecosystems are subject to special protection which takes into account their role and importance in the conservation of marine biological diversity and maintaining coastal balances". This article is therefore of a theoretical nature and does not clearly justify the methods of ecosystem management.

Several policies and strategies are also defined for the sustainable management of Cameroon's mangrove ecosystems (FAO, 2006) [29]. These strategic axes are difficult to apply, due to the diversity of actors and decision-makers who are defined as responsible for the management of the canopy (Ministry of Forests and Wildlife, Ministry of the Environment, Nature Protection and Sustainable Development, Ministry of Fisheries and Animal Industries, etc.), and which do not always act in concert. The mangrove environment faces conflicts over the attribution of responsibilities resulting in a lack of supervision by public authorities, especially in sites that have undergone reforestation operations by a multi-stakeholder partnership. This is the case of the reforestation carried out in the mangrove forest of Bois des Singes in 2005 by the University of Douala, the Cameroonian Network for the Conservation of Mangrove Ecosystems, the Yabassi Fisheries Research Institute.

\subsection{Original of the Study Compared to Other Work Carried out in the Mangrove Environment}

The results of this study illustrate a total loss of an area of mangrove initially estimated at 467.11 hectares. This study stands out from the others because it presents recent data on the evolution of mangroves near Douala International 
Airport. It is a well-defined environment, which in the 1974s was still a dense and very little disturbed mangrove forest. Several authors such as Nfotabong (2011) [30], Moutila Beni (2013) [31], have studied this cover. The study carried out by Nfotabong presented canopy dynamics between 1974 and 2009, without however highlighting the mangrove in the Bois des Singes. Furthermore, the diachronic analysis presented by the author is limited to the 1974-2009 interval, unlike this study, which is a decade longer than the previous one. It also presents the entire expanse of mangrove forest in the Bois des Singes. The study carried out by Beni (2013) [31] focused exclusively on the pressure and dynamics of the coastal mangrove area of Youpwê. It does not present a diachronic analysis clearly carried out to show the changes in a delimited time step. The present study further justifies its originality with regard to the three parameters highlighted, namely the temporal interval (1974-2020), the spatial delineation (the mangrove near the airport which is grouped in 3 districts namely Youpwê, New-priso and Bois des Singes), statistical analysis of changes over the years. Nevertheless, this observed dissimilarity; there is a similarity in the approach used to justify the dynamics of the vegetation cover. The diachronic analysis in question has also been used by other authors such as Bassene et al. (2013) [13], Kana C et al. (2019) [32], Orekan et al. (2019) [16]. This work, which is carried out on separate sites, has the contiguity of illustrating a spatiotemporal degradation of the mangrove to the detriment of human activities.

\section{Conclusion}

The main objective of this study was to show the dynamics of the mangroves near the airport between 1970 and 2020. The results of the study reveal a regressive evolution of the cover due to human activities. Between 1970 and 2012, the mangrove cover decreased respectively from 467.11 to minus 212.56 hectares (with 74.99 of virgin mangrove and 137.16 ha of cover remaining degraded). The more recent observations (2020) illustrate a total conversion of mangrove cover into developed space. This disproportionate anthropization of a space initially made up of mangroves is linked to several factors, namely population growth (which leads to a spatial extension of buildings), the economic development of Douala (economic capital of Cameroon), abusive exploitation and absence of a real sustainable management policy for the mangrove in Cameroon. In addition to constituting a space used by man for constructions, the mangrove is full of essential natural resources such as the red mangrove tree (this species constitutes the main woody plant of the mangrove in the study area) which is exploited by loggers and households. The red mangrove tree is therefore exploited for heating and construction. This species is distinguished from others not only by its strong calorific property to burn even in the fresh state, but also because of the color and the particular taste that it would give to the wildlife products processed by drying. The exploitation of the sand, which is a lucrative activity carried out by the residents, also contributes to the destruction of the mangrove, because it in- 
volves the liberation of the mangrove subsoil, and consequently the uprooting of the plant populations of the environment. The depletion of the substrate, which is also exploited for the backfilling of flood-prone sites, also reduces the development of a juvenile facies of the mangrove. Indeed, the dissemination of propagules (which takes place by hydrochory, zoochory and by winds) is difficult in an intertidal space devoid of muddy substrate.

\section{Conflicts of Interest}

The authors declare no conflicts of interest.

\section{References}

[1] Cormier-Salem, M.C. (1994) Dynamique et usages de la mangrove dans les pays des rivières du sud (du Sénégal à la SIerra Leone). ORSTOM Éditions, 357 p.

[2] Tomlinson, P.B. (1986) The Botany of Mangroves. Cambridge University Press, Cambridge, $413 \mathrm{p}$.

[3] Nagelkerken, I., Blaber, S.J.M., Bouillon, S., Green, P., Haywood, M., Kirton, L.G., Meynecke, J.O., Pawlik, J., Penrose, H.M., Sasekumar, A. and Somerfield, P.J. (2008) The Habitat Function of Mangroves for Terrestrial and Marine Fauna: A Review. Aquatic Botany, 89, 155-185. https://doi.org/10.1016/j.aquabot.2007.12.007

[4] Spalding, M., Kainuma, M. and Collins, L. (2010) World Atlas of Mangroves. Earthscan, UK and USA, 305 p. https://doi.org/10.4324/9781849776608

[5] Tusinski, A. (2012) The Role of Mangroves in the Design of Coastal Dikes-Hydrodynamic and Cost Related Aspects. Master Thesis, Delft University of Technology (TUD).

[6] Taillardat, P. (2013) Flux de $\mathrm{CO}_{2}$, dynamique du carbone et influence des variables environnementales dans la mangrove: Une étude de cas basée dans le delta du fleuve Rouge (parc national de Xuan Thuy, district de Giao Thuy, Vietnam). Mémoire de Maitrise en Sciences de l'Environnement, Université du Québec à Montréal, Montréal, 117 p.

[7] Chan, H.T. and Baba, S. (2009) Manual on Guidelines for Rehabilitation of Coastal Forests Damaged by Natural Hazards in the Asia-Pacific Region. International Tropical Timber Organization, International Society for Mangrove Ecosystems, 66 p.

[8] FAO (2018) Évaluation finale du projet "Gestion communautaire durable et conservation des écosystèmes de mangroves au Cameroun”. FAO, Rome, $50 \mathrm{p}$.

[9] Kuenzer, C., Bluemel, A., Gebhardt, S., Quoc, T.V. and Dech, S. (2011) Remote Sensing of Mangrove Ecosystems: A Review. Remote Sensing, 3, 878-928. https://doi.org/10.3390/rs3050878

[10] Son, N.T., Chen, C.F., Chang, N.B., Chen, C.R., Chang, L.Y. and Thanh, B.X. (2015) Mangrove Mapping and Change Detection in Ca Mau Peninsula, Vietnam, Using Landsat Data and Object-Based Image Analysis. IEEE Journal of Selected Topics in Applied Earth Observations and Remote Sensing, 8, 503-510. https://doi.org/10.1109/JSTARS.2014.2360691

[11] Kanniah, K.D., Sheikhi, A., Cracknell, A.P., Goh, H.C., Tan, K.P., Ho, C.S. and Rasli, F.N. (2015) Satellite Images for Monitoring Mangrove Cover Changes in a Fast Growing Economic Region in Southern Peninsular Malaysia. Remote Sensing, 7, 14360-14385. https://doi.org/10.3390/rs71114360 
[12] Pimple, U., Simonetti, D., Sitthi, A., Pungkul, S., Leadprathom, K., Skupek, H., Som-ard, J., Gond, V. and Towprayoon, S. (2018) Google Earth Engine Based Three Decadal Landsat Imagery Analysis for Mapping of Mangrove Forests and Its Surroundings in the Trat Province of Thailand. Journal of Computer and Communications, 6, 247-264. https://doi.org/10.4236/jcc.2018.61025

[13] Bassene, A.O., Cubizolle, H., Cormier-Salem, M.C. and Boubou, A.S. (2013) L'impact des changements démographiques et socio-économiques sur la perception et la gestion de la mangrove en basse Casamance (Sénégal). Géocarrefour, 88, 299-315. https://doi.org/10.3917/geoc.884.0299

[14] Zogning, L.F.R. (2015) Dynamique des mangroves des marges méridionales de Douala, Etude des cas de Youpwê, New-priso et Bois des Singes dans les périphéries de Douala deuxième. Mémoire de Master en Géographie, Université de Yaoundé 1, Yaoundé, $162 \mathrm{p}$.

[15] Boubacar, S., El Hadji, B.D., Tidiane, S. and Amadou, T.D. (2018) Dynamique de la mangrove de Thiobon dans l'estuauire de la casamance (Sénégal) entre 1972 et 2017. European Scientific Journal, 14, 118-133. https://doi.org/10.19044/esj.2018.v14n33p118

[16] Orekan, V., Plagbeto, H., Edea, E. and Sossou, M. (2019) Évolution actuelle des écosystèmes de mangrove dans le littoral béninois. HAL, $16 \mathrm{p}$. https://archives-ouvertes.fr/

[17] Zogning, L.F.R. (2021) Pressions humaines et stratégies de gestion durable des formations de mangrove de Tiko (Sud-ouest Cameroun). Thèse de Doctorat en Géographie, Spécialité Dynamique de l'Environnement et Risqué, Mémoire de Master en Géographie, Université de Yaoundé 1, 382 p.

[18] FAO (2005) Évaluation des ressources forestières mondiales: Étude thématique sur les mangroves du Cameroun. Rapport, Rome, 8 p.

[19] MINEPDED and RCM (2016) Les mangroves du Cameroun: État des lieux et gestion. $132 \mathrm{p}$.

[20] MINEPDED and RCM (2017) Atlas des mangroves du Cameroun. 83 p.

[21] Yemmafouo, A., Keumo, S.R., Ngouanet, C. and Dzalla, N.G.-C. (2017) Étalement urbain et expansion des plantations industrielles. Les forêts de l'estuaire du Wouri dans l'entre-deux. RIGAGER, 2, 173-186.

[22] MINEP (2010) Études préliminaires de la deuxième phase du projet de conservation et de gestion participative des écosystèmes de mangrove au Cameroun. Rapport Final, $125 \mathrm{p}$.

[23] Patakamuri, S.K., Agrawal, S. and Krishnaveni, M. (2014) Time-Series Analysis of MODIS NDVI Data Along with Ancillary Data for Land Use/Land Cover Mapping of Uttarakhand. The International Archives of the Photogrammetry, Remote Sensing and Spatial Information Sciences, XL-8, 1491-1500. https://doi.org/10.5194/isprsarchives-XL-8-1491-2014

[24] Mainet, G. (1985) Douala: Croissance et servitudes. L’Harmattan, Paris, 611 p.

[25] Din, N., Saenger, P., Priso, R.J., Dibong, D.S. and Blasco, F. (2008) Logging Activities in Mangrove Forests: A Case Study of Douala Cameroon. African Journal of Environmental Science and Technology, 2, 22-30.

[26] Dzalla Ngangue, G.C. (2013) La mangrove de l'estuaire du Wouri (Douala-Cameroun): Enjeux de l'anthropisation d'un écosystème humide tropical et impacts environnementaux. Thèse de Doctorat en Géographie, Université de Douala, Douala, 447 p. 
[27] WRM (2013) Indonésie: Des mangroves pour la vie. Bulletin 192.

[28] République du Cameroun (1996) Loi $\mathrm{n}^{\circ} 96 / 12$ du 05 Août 1996 portant loi-cadre relative à la gestion de l'environnement. $17 \mathrm{p}$.

[29] FAO (2006) Politique et stratégies pour la gestion durable des écosystèmes de mangrove du Cameroun. Rapport, TCP/CMR/2908, 36 p.

[30] Nfotabong, A. (2011) Impacts des activités anthropiques sur la structure de la végétation des mangroves de Kribi, de l'embouchure du fleuve Nyong et de l'estuaire du Cameroun. Thèse de Doctorat, Département de Biologie des Organismes, Université de Douala, Douala, 255 p.

[31] Moutila, B.L. (2013) Pression et dynamique de l'espace côtier à mangrove de Youpwê (Douala). XVI Colloque International du SIFEE Communication Orale, 27 p.

[32] Kana, C.E., Chrétien, N., Alexandra, C.T.T. and René, B.J.T. (2019) Potentiel de l'imagerie multi-capteur dans le suivi des mangroves de l'estuaire du Wouri-Cameroun. Conférence OSFACO: Des images satellites pour la gestion durable des territoires en Afrique, Cotonou, Benin, 13-15 March 2019, 25 p. 